\title{
Maastricht University Graduate Surveys 2021
}

Citation for published version (APA):

Aarts, B., \& Künn, A. (2021). Maastricht University Graduate Surveys 2021. ROA. ROA Fact Sheets No. $001 \mathrm{https}: / /$ doi.org/10.26481/umarof.2021001

Document status and date:

Published: 13/09/2021

DOI:

10.26481/umarof.2021001

Document Version:

Publisher's PDF, also known as Version of record

\section{Please check the document version of this publication:}

- A submitted manuscript is the version of the article upon submission and before peer-review. There can be important differences between the submitted version and the official published version of record.

People interested in the research are advised to contact the author for the final version of the publication, or visit the DOI to the publisher's website.

- The final author version and the galley proof are versions of the publication after peer review.

- The final published version features the final layout of the paper including the volume, issue and page numbers.

Link to publication

\footnotetext{
General rights rights.

- You may freely distribute the URL identifying the publication in the public portal. please follow below link for the End User Agreement:

www.umlib.nl/taverne-license

Take down policy

If you believe that this document breaches copyright please contact us at:

repository@maastrichtuniversity.nl

providing details and we will investigate your claim.
}

Copyright and moral rights for the publications made accessible in the public portal are retained by the authors and/or other copyright owners and it is a condition of accessing publications that users recognise and abide by the legal requirements associated with these

- Users may download and print one copy of any publication from the public portal for the purpose of private study or research.

- You may not further distribute the material or use it for any profit-making activity or commercial gain

If the publication is distributed under the terms of Article $25 \mathrm{fa}$ of the Dutch Copyright Act, indicated by the "Taverne" license above, 
Maastricht University $\&$ ROA

\section{Maastricht University Graduate Surveys 2021}

Bas Aarts

Annemarie Künn

\section{ROA Factsheet}

ROA-F-2021/1

Researchcentrum voor Onderwijs en Arbeidsmarkt | ROA Research Centre For Education and the Labour Market / ROA 


\section{Maastricht University Graduate Surveys 2021}

Like every year, this factsheet reports on the employability of UM alumni. How well does Maastricht University (UM) prepare its students for the labour market? What do the career paths of UM alumni look like in the short and medium term? How do UM alumni look back on their master's studies in Maastricht? We report these Key Performance Indicators for the UM as a whole as well as for the separate faculties. The factsheet is based on alumni research among three cohorts that participated in a survey in 2020. The first cohort graduated in the academic year 2018-2019 (1.5 years prior to the survey), the second in 2014-2015 (five years prior to the survey) and the third in 2009-2010 (ten years prior to the survey).' This year, we discuss the results also in light of the current COVID-19 situation, which has affected the labour market as a severe economic crisis. ${ }^{2}$

Additionally, we shed light on the societal impact UM alumni make in the global labour market. We report on the perceived (relative) importance of the role of social responsibility in their careers. Moreover, we show one indication for their degree of global citizenship.

\section{Position in the labour market}

Of all Maastricht University alumni who graduated 1.5 years ago, $93 \%$ is reported to be part of the labour force. Of those not currently in the labour force, $71 \%$ are still studying. ${ }^{3}$ Five and ten years after graduation more alumni are part of the labour force, namely $98 \%$. Five years after graduation $50 \%$ of those not currently in the labour force are still studying, whereas the percentage of alumni who are still studying ten years after graduation is much lower, namely $22 \%$.

\section{Unemployment}

Figure 1 shows the trend in the unemployment rate from 2005 to 2020 among UM alumni who graduated 1.5 years before the survey. ${ }^{4}$ The unemployment rate is defined as the proportion of alumni belonging to the labour force who are currently not working but are seeking work. From 2013 till 2018 the unemployment rate declined, in line with the recovery from the economic crisis. Between 2018 and 2019, we observed a small increase in the unemployment rate from $4.8 \%$ to $5.5 \%$. Between 2019 and 2020, the unemployment rate has increased on a higher speed, resulting in a $7.0 \%$ unemployment rate in 2020. This accelerated increase in unemployment is likely to be related to the COVID-19 crisis. ${ }^{5}$

FIGURE 01.

Trends in unemployment rates 1.5 years after graduation

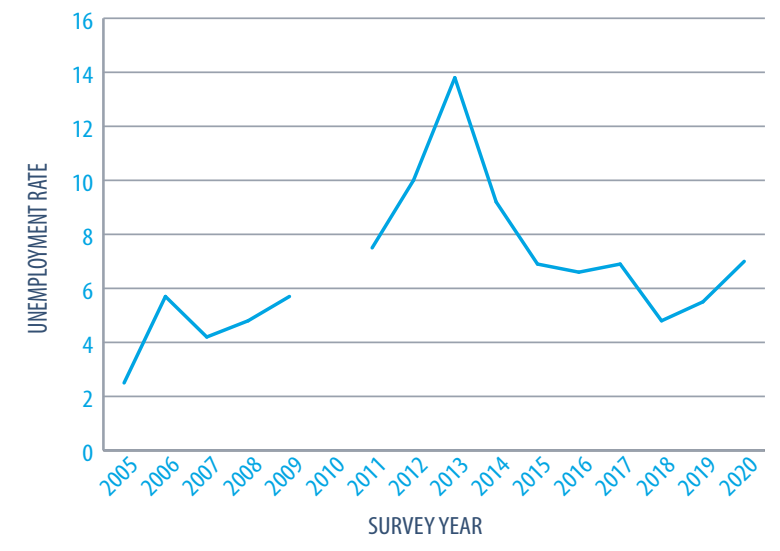

Table 1 gives an overview of graduates' unemployment rates by cohort and faculty. The unemployment rate of the cohorts that graduated five and ten years ago is $2 \%$. As this is similar to last year, the COVID-19 crisis seem to only hit the unemployment rates of the newcomers on the labour market. This is in line with school leavers being hit hardest in times of economic crises. ${ }^{6}$
1 The response rates for these graduation cohorts are: $31.7 \%$ for $2018-2019,37.2 \%$ for $2014-2015,30.4 \%$ for $2009-2010$. The response rate for the $2018-2019$ cohort is based on completed surveys.

2 See: COVID-19 to Plunge Global Economy into Worst Recession since World War II (worldbank.org)

3 Based on the ILO definition of the labour force.
4 The trends five and ten years ago are not shown as they display little variation over time. See for faculty specific unemployment trends, Table 11 in the appendix.

5 In comparison, the unemployment rate of applied university graduates (full-time students) rose from 4.0 to $4.8 \%$ between 2019 and 2020, after a small rise in 2017 (HBO-Monitor 2020).

6 Belfi et al. (2018) Schoolverlaters in crisistijd: Gevolgen voor leren en de vroege loopbaan. ROA-R-2018/7. 


\section{Factsheet}

ROA-F-2021/1

TABLE 01.

Percentage of alumni who are unemployed

\begin{tabular}{|l|c|c|c|} 
& \multicolumn{3}{|c|}{ \% unemployed } \\
\hline Science and Engineering & $2018-2019$ & $2014-2015$ & $2009-2010$ \\
\hline Business and Economics & $X$ & $X$ & $X$ \\
\hline Health, Medicine and Life Sciences & 5 & 0 & 2 \\
\hline Arts and Social Sciences & 4 & 1 & 2 \\
\hline Psychology and Neuroscience & 9 & 4 & 4 \\
\hline Law & 9 & 6 & 0 \\
\hline Maastricht University & 7 & 2 & 3 \\
\hline X & & 2 & 2 \\
\hline
\end{tabular}

$X=$ insufficient data

Unemployment rates vary considerably across faculties, as shown in Table 1.? The highest unemployment rate was found among alumni of FASoS (Faculty of Arts and Social Sciences) 1.5 years after graduation (15\%). This percentage is much higher than for alumni who graduated from other faculties in the same year, and much higher than the percentage of unemployed alumni of the same faculty who graduated five and ten years ago. Compared to last year and the other faculties, it is also the largest increase, namely an increase of 5 percentage points. Alumni of SBE (School of Business and Economics) also show a strong increase in the unemployment rate compared to last year, namely from $1 \%$ to $5 \%$. Among alumni of various faculties, we see that the unemployment rate remains stable or has even decreased. A strong decrease can be seen by alumni of FPN (Faculty of Psychology and Neuroscience), where the unemployment rate dropped from $12 \%$ to $9 \%, 1.5$ years after graduation.

\section{Vertical and horizontal match}

It is not only important to have a job; job requirements should also match the alumni's education. A suitable job is one that makes use of the knowledge and skills acquired during the graduate's studies. Such jobs are often linked to higher job satisfaction, better career

7 The unemployment rate is different within FHML. The unemployment rate for Health and Life Sciences alumni is $6 \%, 2 \%$ and $3 \%$ respectively. The unemployment rate among Medicine alumni is considerably lower: $0 \%, 0 \%$ and $1 \%$ respectively. opportunities and less sick leave ${ }^{8}$, and even to higher life satisfaction. ${ }^{9}$

Table 2a shows the extent to which UM graduates experience a vertical match (i.e. whether they are working in a job that requires a master's degree)..$^{10}$ Overall, $72 \%$ of the UM graduates are working at master's level or higher 1.5 years after graduation. This percentage is slightly higher compared to the recent graduates from last year (69\%). Five years after graduation we find that $74 \%$ of the UM alumni are working at master's level or higher. This percentage is much higher for the cohort that graduated ten years ago, namely $84 \%$. It seems to be the case that time after graduation relates positively to the probability of working in a job that requires a master's degree.

There are several differences across faculties. Similar to last year, we see relatively high proportions of graduates of all cohorts with a good vertical match among alumni of FHML (Faculty of Health, Medicine and Life Sciences). ${ }^{11}$ Also among alumni of FPN we see high proportions of vertical match. Among LAW graduates we see an increase in vertical match among alumni who graduated 1.5 years ago compared to last year (from $64 \%$ to $70 \%$ ).

8 See e.g. Lee, Y., \& Sabharwal, M. (2016). Education-job match salary, and job satisfaction across the public, non-profit, and for-profit sectors: Survey of recent college graduates. Public Management Review, 18(1), 40-64.

9 See e.g. Ilies, R., Yao, J., Curseu, P. L., \& Liang, A. X. (2019). Educated and happy: a four-year study explaining the links between education, job fit, and life satisfaction. Applied Psychology, 68(1), 150-176.

10 Since 2018, we report the percentage of UM alumni working in a job that requires an HBO-master or university-master.

11 There are differences in vertical match among FHML alumni. The percentages of Health and Life Sciences alumni with a vertical match are $72 \%, 72 \%$ and $84 \%$ respectively. In contrast, all Medicine alumni are vertically matched irrespective of cohort. 


\section{Maastricht University Graduate Surveys 2021}

TABLE 02a.

Percentage of alumni with a good vertical match

\begin{tabular}{|l|c|c|c|}
\hline & \multicolumn{3}{|c|}{$\%$ working at master's level or higher } \\
\hline Science and Engineering & $2018-2019$ & $2014-2015$ & $2009-2010$ \\
\hline Business and Economics & X & X & X \\
\hline Health, Medicine and Life Sciences & 62 & 72 & 79 \\
\hline Arts and Social Sciences & 81 & 82 & 91 \\
\hline Psychology and Neuroscience & 60 & 60 & 71 \\
\hline Law & 71 & 77 & 93 \\
\hline Maastricht University & 70 & 75 & 87 \\
\hline X insufficient data & 72 & 74 & 84 \\
\hline
\end{tabular}

Table $2 b$ shows the percentage of Maastricht University graduates that is currently working in their own field of study or a related field of study, the so-called horizontal match. Most graduates succeed in finding a job in a field that aligns with their field of study.

Of the cohort 1.5 year after graduation $76 \%$ is horizontally well-matched, whereas for the cohorts five and ten years after graduation $79 \%$ and $76 \%$ respectively are horizontally well-matched. Again, we see differences across faculties, comparable to last year's survey. The percentage of alumni with a good horizontal match is relatively high for all cohorts of FHML. ${ }^{22} \mathrm{FPN}$ alumni 1.5 and five years after graduation have aboveaverage probability of holding a job in their own or related field of study.

\section{TABLE 02b.}

Percentage of alumni with a good horizontal match

\begin{tabular}{|l|c|c|c|}
\hline & \multicolumn{3}{|c|}{$\%$ working in own or related field of study } \\
\hline Science and Engineering & $2018-2019$ & $2014-2015$ & $2009-2010$ \\
\hline Business and Economics & X & X & X \\
\hline Health, Medicine and Life Sciences & 71 & 80 & 79 \\
\hline Arts and Social Sciences & 82 & 84 & 79 \\
\hline Psychology and Neuroscience & 66 & 62 & 61 \\
\hline Law & 81 & 81 & 70 \\
\hline Maastricht University & 73 & 78 & 76 \\
\hline X insuficient data & 76 & 79 & 76 \\
\hline
\end{tabular}

$X=$ insufficient data

12 There are differences in horizontal match among FHML alumni. The percentages of Health and Life Sciences alumni with a good horizontal match are are $78 \%, 76 \%$ and $66 \%$ respectively. Among Medicine alumni, these figures are $91 \%, 99 \%$ and $96 \%$.

\section{Income and working hours}

Table 3 shows the median monthly gross income of UM alumni and their weekly working hours. On average, UM graduates 1.5 years after graduation have a median monthly income of $€ 2825$. This increases to $€ 3800$ and $€ 5000$, respectively five and ten years after graduation.

Across faculties, there are differences in terms of median income. Alumni of SBE and $\mathrm{FHML}^{13}$ start with a relatively high income of $€ 3000$. Also among alumni who graduated ten years ago, we see a relatively high median monthly income among SBE and FHML graduates, respectively $€ 5693$ and $€ 5000$. It should be noted that SBE graduates also report a relatively high median weekly working hours.

Compared to last year, $\mathrm{FHML}^{14}$ graduates who graduated ten years ago report to work more hours per week (from 36 to 38 hours) and earn more on a monthly basis (median income from $€ 4500$ to $€ 5000$ ).

13 The median monthly income is different within FHML. Alumn of Health and Life Sciences have a median income of $€ 2791$, $€ 3300, € 4000$ (1.5, five and ten years after graduation). Whereas alumni of Medicine have a median income of $€ 3700, € 4300$ and $€ 6500$.

14 There are differences in regular working hours per week among FHML alumni. Alumni of Health and Life Sciences have regular working hours of 38,38 and 36 hours per week, respectively. Whereas alumni of Medicine have regular working hours of 38,45 and 40 hours per week. 


\section{Factsheet}

ROA-F-2021/1

TABLE 03.

Median monthly income and weekly working hours

\begin{tabular}{|l|c|c|c|c|c|c|}
\hline & \multicolumn{3}{|c|}{ Gross income per month (median) } & \multicolumn{3}{c|}{ Regular working hours per week (median) } \\
\hline Science and Engineering & $2018-2019$ & $2014-2015$ & $2009-2010$ & $2018-2019$ & $2014-2015$ & $2009-2010$ \\
\hline Business and Economics & $\mathrm{X}$ & $\mathrm{X}$ & $\mathrm{X}$ & $\mathrm{X}$ & $\mathrm{X}$ & $\mathrm{X}$ \\
\hline Health, Medicine and Life Sciences & 3000 & 4538 & 5693 & 40 & 42 & 42 \\
\hline Arts and Social Sciences & 3000 & 3700 & 5000 & 38 & 40 & 38 \\
\hline Psychology and Neuroscience & 2200 & 3000 & 3650 & 40 & 40 & 40 \\
\hline Law & 2150 & 3088 & 4100 & 36 & 39 & 40 \\
\hline Maastricht University & 2830 & 3800 & 4550 & 40 & 40 & 40 \\
\hline
\end{tabular}

$\mathrm{X}=$ insufficient data

\section{Societal impact in a global labour market}

At Maastricht University, students from all over the world learn together in small, diverse groups by solving problems which often correspond to real problems in society. ${ }^{15}$ By this, the university prepares its students to realize societal impact when entering the global labour market. Two aspects are important here. First, the university aims to educate global citizenship, which is defined as awareness, caring, and embracing cultural diversity while promoting social justice and sustainability, coupled with a sense of responsibility to act. Individuals who are identified as global citizens are globally aware, express caring and empathy for others, embrace cultural diversity, promote social justice and environmentally sustainable living, and feel a responsibility to transform society. Second, the university aims to create societal impact. The UM takes its social responsibility seriously by linking the university to society. This is done via research but also in preparing students to be able to solve problems and come up with creative ideas.

In the second part of this factsheet, we show, based on the 2020 survey, how socially responsible UM graduates are. ${ }^{16}$ Moreover, we show an indicator related to global citizenship.

Table 4 shows the percentage of alumni who indicated that they contribute to a (very) large extent to social matters in their job. The differences between the two cohorts seem to be relatively small. In general, two out

15 See brochure 'Our impact on Maastricht, Europe and the world' at www.maastrichtuniversity.nl/about-um/organisation/ mission-strategy.

16 In Figures 2 and 3, we also use the 2018 and 2019 surveys. of three UM alumni indicate to contribute to a (very) large extent to social matters in their job. This is slightly below the finding from Dur and Van Lent (2018). ${ }^{17}$ They found that $75 \%$ (strongly) agreed with the statement" My job is useful to society".18

At the faculty level, FHML alumni $(76 \% \text { and } 82 \%)^{19}$ and FPN alumni (74\% and 76\%) stand out. Graduates from SBE score below average in contributing to a (very) large extent in social matters in their job (54\%). Again, this is in line with findings from Dur and Van Lent (2018). They find that "sales, marketing, and public relations professionals" and "economists" belong to the top-20 occupations in which workers report socially useless jobs most.

17 Dur, R., \& Van Lent, M. (2019). Socially useless jobs. Industrial Relations: A Journal of Economy and Society, 58(1), 3-16.

18 Their sample includes more than 27,000 workers in thirtyseven countries. Their data is from 2015.

19 Alumni of Health and Life Sciences differed from alumni of Medicine with regard to contributing to social matters in their job: $72 \%$ and $73 \%$ for Health and Life Sciences alumni versus $82 \%$ and $89 \%$ for Medicine alumni. 


\section{Maastricht University Graduate Surveys 2021}

TABLE 04.

Percentage of alumni who contribute to a (very) large extent to social matters in their job

\begin{tabular}{|l|c|c|} 
& \multicolumn{3}{|c|}{$\begin{array}{c}\text { \% of alumni contribute to social matters } \\
2014-2015\end{array}$} & 2009-2010 \\
\hline Science and Engineering & $\mathrm{X}$ & $\mathrm{X}$ \\
\hline Business and Economics & 54 & 54 \\
\hline Health, Medicine and Life Sciences & 76 & 82 \\
\hline Arts and Social Sciences & 69 & 70 \\
\hline Psychology and Neuroscience & 74 & 76 \\
\hline Law & 67 & 69 \\
\hline Maastricht University & 66 & 69 \\
\hline
\end{tabular}

$X=$ insufficient data

Figure 2 shows the trend in contributing to social matters measured between $2017-2020^{20}$ among UM alumni who graduated five years before the survey. FHML stands out. About $80 \%$ of all FHML graduates contribute to a (very) large extent to social matters in their job. Over the years, the percentages have changed only slightly. There is only one exception: Among SBE alumni, there was an almost 10 percentage points increase (from $45 \%$ to $54 \%$ ) in the percentage of SBE alumni that contribute to a (very) large extent to social matters in their job.

\section{FIGURE 02.}

Trends in percentage of alumni who (very) strongly contribute to social matters (five years after graduation)

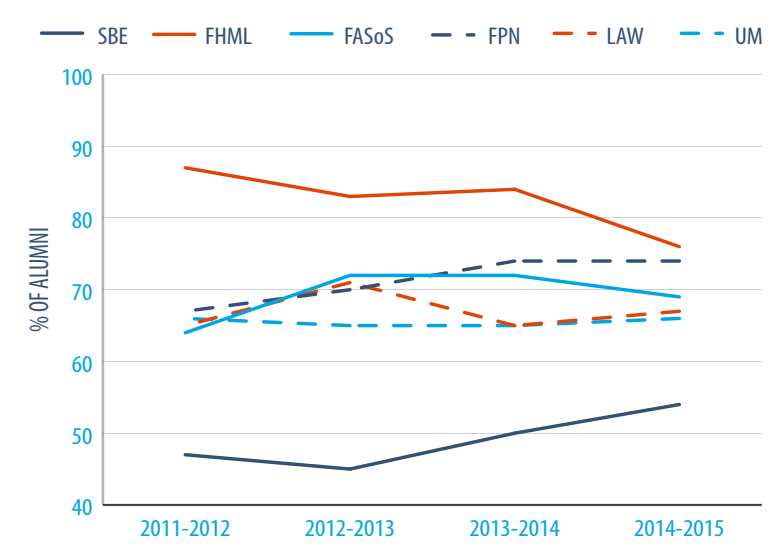

Figure 3 shows the trend in (strongly) contributing to social matters among UM alumni who graduated ten years before the survey. As in Figure 2, it can be seen

20 This information is only availble in these years. that alumni from FHML, contribute more to social matters in their job compared to alumni from other faculties though the differences between other faculties are slightly smaller. Again, it can be noted that among SBE graduates in particular, the percentages increased relatively strongly, from $45 \%$ for the 2007-2008 cohort to $54 \%$ for the $2009-2010$ cohort. Among alumni from LAW, there seems to be a decrease in the percentage of alumni who contribute (very) strongly to social matters (from $76 \%$ to $69 \%$ ).

\section{FIGURE 03.}

Trends in percentage of alumni who (very) strongly contribute to social matters (ten years after graduation)

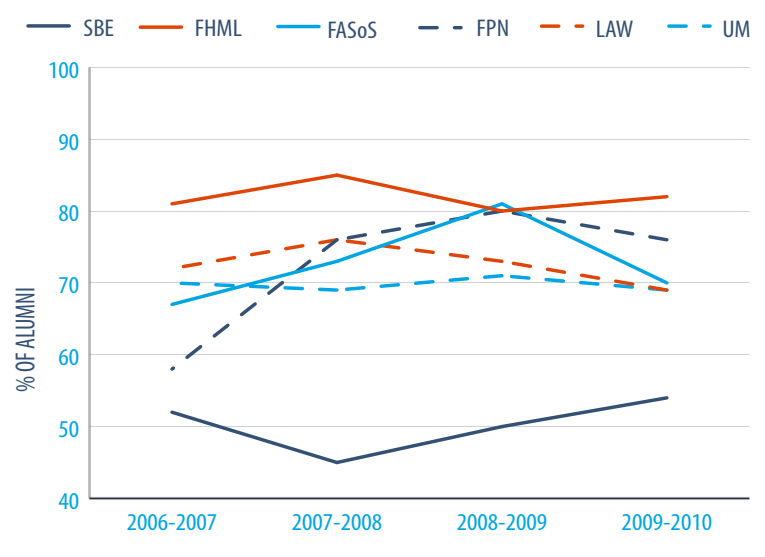

Table 5 shows the percentage of alumni who indicated that they (very) strongly influenced an organisation from within to take greater social responsibility. ${ }^{21}$ This statement is stronger than the one used for Figures 2 and 3 , and relates to global citizenship. On average, five and ten years after graduation $57 \%$ and $61 \%$ of UM alumni indicate that they (very) strongly influence an organisation from within to take greater social responsibility.22 There are small differences between faculties and cohorts. Except for LAW alumni of all faculties, seem to influence organisations to take greater social responsibility slightly more when graduated ten compared to five years ago. FPN alumni of both

21 This question is one way of measuring global citizenship. See Murphy, D., Sahakyan, N., Yong-Yi, D., \& Magnan, S. S. (2014). The impact of study abroad on the global engagement of university graduates. Frontiers: The Interdisciplinary Journal of Study Abroad, 24(1), 1-24.

22 This question is added in the 2020 wave, so it is not possible to comment on trends. 


\section{Factsheet}

ROA-F-2021/1

cohorts score below UM average; whereas FHML alumni graduated in 2009-2010 score clearly above UM-average..$^{23}$

\section{TABLE 05.}

Percentage of alumni who (very) strongly influence an organisation from within to take greater social responsibility

\begin{tabular}{|l|c|c|}
\hline & $\begin{array}{c}\text { \% of alumni influenced an organisation to } \\
\text { take greater social responsibility }\end{array}$ \\
\hline \begin{tabular}{l|l}
$2014-2015$ \\
Science and Engineering
\end{tabular} & $\mathrm{X}$ & $\mathrm{X}$ \\
\hline Business and Economics & 55 & 58 \\
\hline Health, Medicine and Life Sciences & 55 & 70 \\
\hline Arts and Social Sciences & 62 & 64 \\
\hline Psychology and Neuroscience & 50 & 52 \\
\hline Law & 63 & 54 \\
\hline Maastricht University & 57 & 61 \\
\hline X = insufficient data & & \\
\hline
\end{tabular}

\section{TABLE 06.}

Percentage of alumni who find social commitment (very) important when looking for a job

\begin{tabular}{|l|c|}
\hline & \% of alumni social commitment \\
& 2014-2015 \\
\hline Science and Engineering & $\mathrm{X}$ \\
\hline Business and Economics & 58 \\
\hline Health, Medicine and Life Sciences & 72 \\
\hline Arts and Social Sciences & 65 \\
\hline Psychology and Neuroscience & 60 \\
\hline Law & $\mathrm{X}$ \\
\hline Maastricht University & 64 \\
\hline
\end{tabular}

$X=$ insufficient data

Note: We are unable to present data for the 2009-2010 cohort due to insufficient graduates looking for a job.

Table 6 shows the percentage of alumni who find social commitment (very) important when looking for a(n other) job. Overall, five years after graduation $64 \%$ of UM alumni ${ }^{24}$ indicate that they find social commitment (very) important when looking for a job. Alumni from FHML most often consider social commitment (very) important when looking for a job.

23 There are small differences between alumni of Health and Life Sciences and alumni of Medicine with regard to influencing an organisation from within to take greater social responsibility: $54 \%$ and $68 \%$ for Health and Life Sciences alumni versus $57 \%$ and $72 \%$ for Medicine alumni.

24 We have too few observations to be able to present the results of Medicine and Health and Life Sciences separately.
Up until now, we have an indication about the degree to which UM alumni are socially responsible. However, we have not yet addressed the relative importance of social responsibility in the context of other careerrelated aspects. Table 7 shows the results of the ranking of nine career aspects of UM alumni five and ten years after graduation. ${ }^{25} \mathrm{~A}$ higher rank, means more important. We find that five and ten years after graduation, alumni ranked the same two career aspects at position one and two, namely job content and good career prospects. ${ }^{26}$ Lifelong learning, a high salary and job security also rank in the top 5. Realizing social impact, is ranked at position six by alumni who graduated five years ago, and at position seven by alumni who graduated ten years ago. Compared to other career aspects, realizing social impact is not considered the most important but also not the least important career aspect. Being mobile on the labour market and having a job in own field of study are ranked lower.

\section{TABLE 07.}

Ranking of career aspects by two graduation cohorts

\begin{tabular}{|l|c|c|}
\hline & 2014-2015 & 2009-2010 \\
\hline 1 & Job content & Job content \\
\hline 2 & Good career prospects & Good career prospects \\
\hline 3 & Lifelong learning & High salary \\
\hline 4 & High salary & Job security \\
\hline 5 & Job security & Lifelong learning \\
\hline 6 & Realizing social impact & Job at master level \\
\hline 7 & Job at master level & Realizing social impact \\
\hline 8 & Job in own field of study & Job in own field of study \\
\hline 9 & Being mobile on the labour market & Being mobile on the labour market \\
\hline
\end{tabular}

In Table 8 we show the position of realizing social impact per faculty for alumni who graduated five and ten years ago. There does not seem to be large differences across faculties for the 2014-2015 cohort. Alumni of all cohorts rank social impact either fifth or sixth, except for FPN alumni (rank 7). Among the alumni who graduated ten years ago, we see slightly more differences. FASoS and

25 For creating the ranking, we make use of the Borda counting method.

26 The ranking is very similar to the one from the 2019 survey. 


\section{Maastricht University Graduate Surveys 2021}

SBE alumni rank social impact fifth and sixth, whereas $\mathrm{FHML}^{27}$ and FPN alumni ranked social impact eighth.

TABLE 08.

Ranking of realizing social impact by faculty and two graduation cohorts

\begin{tabular}{|l|c|c|}
\hline & 2014-2015 & 2009-2010 \\
\hline Science and Engineering & $X$ & 6 \\
\hline Business and Economics & 6 & 8 \\
\hline Health, Medicine and Life Sciences & 5 & 5 \\
\hline Arts and Social Sciences & 5 & 8 \\
\hline Psychology and Neuroscience & 7 & 7 \\
\hline Law & 5 & 7 \\
\hline Maastricht University & 6 & X \\
\hline
\end{tabular}

$X=$ insufficient data

Note: $1=$ most important career aspect, $9=$ least important career aspect

Table 9 shows, based on the national questionnaire among graduates from the 2018-2019 cohort, the percentage of alumni who have to a (very) large extent competencies related to social impact. Overall, about two-thirds of UM alumni indicated an ability to contribute to the development and/or implementation of new ideas to a (very) large extent. At the faculty level, FASoS alumni scored above UM average; FHML ${ }^{28}$ alumni and LAW alumni scored below the UM average. The ability to solve problems in new or unknown situations seems to be higher on average. Three out of four UM alumni indicate that they are able to master this. ${ }^{29}$ At the faculty level, SBE alumni stand out with $82 \%$. FPN alumni score below the UM average. Regarding being able to taking into account societal issues and ethical questions when forming an opinion, $75 \%$ of UM alumni indicate to master this to a (very) large extent. ${ }^{30}$ At faculty level, FASoS alumni stand out with $89 \%$.

TABLE 09.

Percentage of alumni who have to a (very) large extent competencies related to societal impact

\begin{tabular}{|c|c|c|c|}
\hline & $\begin{array}{c}\text { Contributing } \\
\text { to the } \\
\text { development } \\
\text { and/or } \\
\text { implementation } \\
\text { of new ideas }\end{array}$ & $\begin{array}{l}\text { Solving } \\
\text { problems } \\
\text { in new or } \\
\text { unknown } \\
\text { situations }\end{array}$ & $\begin{array}{l}\text { Take into } \\
\text { account } \\
\text { societal } \\
\text { issues and } \\
\text { ethical } \\
\text { questions } \\
\text { when } \\
\text { forming an } \\
\text { opinion }\end{array}$ \\
\hline Science and Engineering & $x$ & $x$ & $x$ \\
\hline Business and Economics & 74 & 82 & 72 \\
\hline Health, Medicine and Life Sciences & 61 & 75 & 74 \\
\hline Arts and Social Sciences & 73 & 77 & 89 \\
\hline Psychology and Neuroscience & 64 & 68 & 74 \\
\hline Law & 59 & 75 & 77 \\
\hline Maastricht University & 66 & 76 & 75 \\
\hline
\end{tabular}

$\mathrm{X}=$ insufficient data

Note: Based on NAE, graduation cohort 2018-2019

\section{Satisfaction with master's programme at Maastricht University}

Table 10 shows the percentage of alumni who would choose the same master's programme at UM again. Of the most recent graduates, $73 \%$ of UM graduates would choose the same programme again. Five and ten years after graduation the percentages are higher, respectively $78 \%$ and $79 \% .{ }^{31}$ Especially among alumni who graduated five years ago we see an increase compared to last year in choosing for the same master's programme at the $\mathrm{UM}$ again. At $\mathrm{FHML}^{32}, 85 \%$ of all alumni graduating in 2009-2010 would choose the same master's programme

30 There are small differences between Health and Life Sciences and Medicine alumni with regard to taking into account societal issues and ethical questions when forming an opinion: $73 \%$ for Health and Life Sciences alumni and $77 \%$ for Medicine alumni.

31 Last year, the percentage of alumni who graduated five and ten years before the survey and would choose the same study programme at UM again was $73 \%$ and $76 \%$ respectively.

32 The percentages for Health and Life Sciences alumni are 74\%, $76 \%$ and $75 \%$ (at 1.5, five and ten years after graduation). The corresponding figures for Medicine alumni are $78 \%, 84 \%$ and $94 \%$, respectively. 


\section{Factsheet}

ROA-F-2021/1

at UM again. This percentage is high compared to other faculties. ${ }^{33}$

TABLE 10.

Percentage of alumni who would choose the same master's programme at UM again

\begin{tabular}{|l|c|c|c|} 
& \multicolumn{3}{|c|}{ \% of alumni who would choose the same } \\
& study at UM again \\
\hline Science and Engineering & X & X & X \\
\hline Business and Economics & 73 & 81 & 78 \\
\hline Health, Medicine and Life Sciences & 75 & 79 & 85 \\
\hline Arts and Social Sciences & 70 & 77 & 72 \\
\hline Psychology and Neuroscience & 68 & 69 & 74 \\
\hline Law & 73 & 79 & 74 \\
\hline Maastricht University & 73 & 78 & 79 \\
\hline X & & & $2009-2010$ \\
\hline
\end{tabular}

$X=$ insufficient data 


\section{Maastricht University Graduate Surveys 2021}

TABLE 11.

Unemployment

\begin{tabular}{|c|c|c|c|c|c|c|c|c|c|c|}
\hline & $\begin{array}{c}2012 \\
T+1 \\
2010-2011\end{array}$ & $\begin{array}{c}2013 \\
T+1 \\
2011-2012\end{array}$ & $\begin{array}{c}2014 \\
T+1 \\
2012-2013\end{array}$ & & $\begin{array}{c}2015 \\
T+1 \\
2013-2014\end{array}$ & $\begin{array}{c}2016 \\
T+1 \\
2014-2015\end{array}$ & $\begin{array}{c}2017 \\
T+1 \\
2015-2016\end{array}$ & $\begin{array}{c}2018 \\
T+1 \\
2016-2017\end{array}$ & $\begin{array}{c}2019 \\
T+1 \\
2017-2018\end{array}$ & $\begin{array}{c}2020 \\
\mathrm{~T}+1 \\
2018-2019\end{array}$ \\
\hline Science and Engineering & & & 13.0 & & 4.0 & 4.7 & 4.8 & 6.3 & X & X \\
\hline Business and Economics & 6.0 & 6.3 & 5.7 & & 3.6 & 0 & 0 & 0.8 & 1.3 & 5.2 \\
\hline Health and Life Sciences & 8.3 & 16.4 & 10.3 & & 9.2 & 8.0 & 7.1 & 2.8 & 5.2 & 5.8 \\
\hline Medicine & 1.7 & 2.5 & 3.3 & & 2.7 & 0 & 3.9 & 0 & 0 & 0 \\
\hline Arts and Social Sciences & 25.5 & 33.3 & 13.7 & & 5.9 & 5.6 & 22.9 & 18.6 & 9.6 & 15 \\
\hline Psychology and Neuroscience & 16.7 & 25.6 & 7.6 & & 10.3 & 14.1 & 7.3 & 8.1 & 11.7 & 8.6 \\
\hline Law & 7.1 & 14.3 & 16.2 & & 10.3 & 14.6 & 7.7 & 4.4 & 9.0 & 9.4 \\
\hline \multirow[t]{2}{*}{ Maastricht University } & 10.0 & 13.8 & 9.2 & & 6.9 & 6.6 & 6.9 & 4.8 & 5.5 & 7.0 \\
\hline & $\begin{array}{c}2012 \\
T+5 \\
2005-2006\end{array}$ & $\begin{array}{c}2013 \\
T+5 \\
2006-2007\end{array}$ & $\begin{array}{c}2014 \\
T+5 \\
2007-2008\end{array}$ & $\begin{array}{c}2015 \\
\text { spring } \\
T+5 \\
2008-2009\end{array}$ & $\begin{array}{c}2015 \\
\text { autumn } \\
\text { T+5 } \\
\text { 2009-2010 }\end{array}$ & $\begin{array}{c}2016 \\
T+5 \\
2010-2011\end{array}$ & $\begin{array}{c}2017 \\
T+5 \\
2011-2012\end{array}$ & $\begin{array}{c}T+5 \\
2012-2013\end{array}$ & $\begin{array}{c}2019 \\
T+5 \\
2013-2014\end{array}$ & $\begin{array}{c}\mathrm{T}+5 \\
2014-2015\end{array}$ \\
\hline Science and Engineering & & & & 0 & 6.0 & 0 & 7.4 & 7.5 & x & X \\
\hline Business and Economics & 1.9 & 0 & 0 & 0.9 & 1.5 & 1.3 & 1.2 & 2.0 & 0.8 & 0.4 \\
\hline Health and Life Sciences & 2.1 & 3.1 & 3.5 & 4.3 & 5.3 & 3.3 & 1.7 & 6.8 & 2.0 & 2 \\
\hline Medicine & 0 & 0 & 1.3 & 0 & 4.9 & 0 & 0 & 1.1 & 0 & 0 \\
\hline Arts and Social Sciences & 10.1 & 5.7 & 4.8 & 4.4 & 6.7 & 1.5 & 5.7 & 5.0 & 1.6 & 3.7 \\
\hline Psychology and Neuroscience & 4.2 & 0 & 4.3 & 7.5 & 2.5 & 4.9 & 4.4 & 3.1 & 6.6 & 6.3 \\
\hline Law & 0 & 6.8 & 3.8 & 2.6 & 1.8 & 0 & 1.6 & 6.5 & 3.3 & 1.9 \\
\hline \multirow[t]{2}{*}{ Maastricht University } & 2.7 & 3.2 & 2.6 & 2.6 & 3.4 & 1.5 & 2.2 & 3.9 & 2.3 & 2.2 \\
\hline & $\begin{array}{c}2012 \\
T+10 \\
2000-2001\end{array}$ & $\begin{array}{c}2013 \\
T+10 \\
2001-2002\end{array}$ & $\begin{array}{c}2014 \\
T+10 \\
2002-2003\end{array}$ & $\begin{array}{c}2015 \\
\text { spring } \\
T+10 \\
2003-2004\end{array}$ & $\begin{array}{c}2015 \\
\text { autumn } \\
\text { T+10 } \\
2004-2005\end{array}$ & $\begin{array}{c}2016 \\
T+10 \\
2005-2006\end{array}$ & $\begin{array}{c}\mathrm{T}+10 \\
2006-2007\end{array}$ & $\begin{array}{c}T+10 \\
2007-2008\end{array}$ & $\begin{array}{c}2019 \\
T+10 \\
2008-2009\end{array}$ & $\begin{array}{c}2020 \\
T+10 \\
2009-2010\end{array}$ \\
\hline Science and Engineering & & & x & $x$ & X & $x$ & X & $x$ & x & x \\
\hline Business and Economics & 0.9 & 0.9 & 0.7 & 1.0 & 0 & 1.6 & 1.1 & 1.1 & 4.2 & 1.8 \\
\hline Health and Life Sciences & 1.2 & 3.1 & 3.7 & 0.6 & 2.6 & 1.6 & 1.4 & 4.5 & 1.3 & 2.7 \\
\hline Medicine & 1.8 & 0 & 2.0 & 3.6 & 1.5 & 1.2 & 0 & 1.7 & 3.4 & 1.2 \\
\hline Arts and Social Sciences & $x$ & $x$ & $x$ & 4.3 & 11.5 & 4.4 & 4.6 & 2.0 & 2.3 & 4.3 \\
\hline Psychology and Neuroscience & 3.8 & 0 & 4.9 & 2.0 & 3.1 & 1.7 & 3.7 & 0 & 0 & 0 \\
\hline Law & 6.1 & 1.6 & 0 & 1.4 & 0 & 0 & 6.9 & 1.7 & 0 & 2.9 \\
\hline Maastricht University & 2.0 & 2.0 & 2.1 & 1.5 & 3.0 & 1.7 & 2.6 & 1.8 & 2.1 & 2.4 \\
\hline
\end{tabular}

$\mathrm{X}=$ insufficient data 
Factsheet

ROA-F-2021/1 


\section{Imprint}

(C) Research Centre for Education and the Labour Market (ROA).

Nothing in this publication may be duplicated in any way

without prior written permission from ROA's director.

\section{Research Centre for Education and the Labour Market}

Maastricht University

School of Business and Economics

secretary-roa-sbe@maastrichtuniversity.nl

www.roa.nl

\section{Layout}

ROA Secretariat, Maastricht

June 2021

ISSN: 2667-0488 